\title{
An update of cancer mortality among chrysotile asbestos miners in Balangero, northern Italy
}

\author{
Giorgio Piolatto, Eva Negri, Carlo La Vecchia, Enrico Pira, Adriano Decarli, Julian Peto
}

\begin{abstract}
The mortality experience of a cohort of chrysotile miners employed since 1946 in Balangero, northern Italy was updated to the end of 1987 giving a total of 427 deaths out of 27010 man-years at risk. A substantial excess mortality for all causes (standardised mortality ratio $(S M R)=149)$ was found, mainly because of high rates for some alcohol related deaths (hepatic cirrhosis, accidents). For mortality from cancer, however, the number of observed deaths (82) was close to that expected $(76 \cdot 2)$. The SMR was raised for oral cancer (SMR 231 based on six deaths), cancer of the larynx (SMR 267 based on eight deaths), and pleura (SMR 667 based on two deaths), although the excess only reached statistical significance for cancer of the larynx. Rates were not increased for lung, stomach, or any other type of cancer. No consistent association was seen with duration or cumulative dust exposure (fibre-years) for oral cancer, but the greatest risks for laryngeal and pleural cancer were in the highest category of duration and degree of exposure to fibres. Although part of the excess mortality from laryngeal cancer is probably attributable to high alcohol consumption in this group of workers, the data suggest that exposure to chrysotile asbestos (or to the fibre balangeroite that accounts for $\cdot 0 \cdot 2$
\end{abstract}

Istituto di Medicina del Lavoro, Università di Torino, 10126 Torino, Italy

G Piolatto, E Pira

Istituto di Ricerche Farmacologiche "Mario Negri", Via Eritrea 62, 20157 Milano, Italy

E Negri, C La Vecchia

Istituto di Biometria e Statistica Medica, Università di Milano, 20133 Milano, and Istituto di Statistica, Università di Trento, 38100 Trento, Italy

A Decarli

Division of Epidemiology, Institute of Cancer Research, Sutton, Surrey SM2 5PX, United Kingdom

J Peto
$0.5 \%$ of total mass in the mine) is associated with some, however moderate, excess risk of laryngeal cancer and pleural mesothelioma. The absence of excess mortality from lung cancer in this cohort is difficult to interpret.

The mortality up to 1975 of a cohort of asbestos workers in the only open air asbestos mine still active in Europe, at Balangero (near Turin, northern Italy), was reported in $1979 .{ }^{1}$ The analysis, based on a total of 332 deaths, showed an excess mortality from all causes (standardised mortality ratio $(S M R)=155)$, mainly due to hepatic cirrhosis, accidents, and other causes potentially related to alcohol, although a substantial excess was also seen for cardiovascular diseases.

By contrast, there was no significant excess mortality from all cancers $(50$ observed $v 47$ expected deaths), nor for cancer of the lung or pleura (11 observed $v 10 \cdot 4$ expected deaths) but a significantly increased SMR for laryngeal cancer was found (six observed $v 1.9$ expected deaths).

In this paper we present the results of 12 more years of follow up on this cohort, to provide further quantitative information on the risk of cancer associated with mining of chrysotile asbestos.

\section{Subjects and methods}

The cohort comprised men who had worked for at least one year at the factory between 1946 and 1987 . Of these, $36(3 \%)$ who could not be traced were excluded leaving 1058 subjects under study.

Dates of birth and employment, last known address, and job categories were obtained from personnel records at the factory. Quantification of the data on exposure was based on cumulative dose of inhaled fibres expressed as fibre-years. This was estimated from environmental measurements carried out from 1969 onwards, and from artificially recreated working conditions for earlier periods. ${ }^{1}$

Vital state after termination of employment was ascertained through population registers and copies of death certificates were obtained from municipal registration offices. For the present analysis, follow 
up began on 1 January 1946 and ended on 31 December 1987. A total of 427 deaths was registered in this period, which encompassed 27010 man-years of observation.

Expected numbers of deaths were computed using national death rates for each five year calendar period and age group. National numbers of certified deaths for each cause and quinquennium of age are published by the Central Institute of Statistics (ISTAT) from $1955 .{ }^{23}$ Rates for the late 1950 s were applied to the period 1946-54. Observed and expected numbers were tabulated by age at first employment, duration of employment, period since start and end of employment, and estimated cumulative dust exposure.

As retirement or change of job may have been due to the disease itself in some cases, employment dates were lagged by one year in calculating exposures. Changing this to two or three years did not appreciably modify the results.

\section{Results}

Table 1 shows the observed and expected numbers of cancer deaths by duration of employment in the mine. The SMR was increased for oral (231), laryngeal (267), and pleural (667) cancer, although this was significant only for laryngeal cancer (eight observed $v$ three expected deaths, $\mathrm{p}<0.05$ ). The SMRs for alcohol related diseases are probably overestimated slightly since national mortality rates were used to compute expected numbers. In the mid1970s the province of Turin had SMRs compared with the whole of Italy of 133 for oral cancer, 117 for laryngeal cancer, and 115 for hepatic cirrhosis, ${ }^{45}$ and an excess mortality from laryngeal cancer was evident in the general population round Balangero. ${ }^{6}$ Mortality in the cohort was not increased for lung, stomach, or any other type of cancer. For these sites, the use of national mortality rates should not have introduced material bias, as the SMR of the province of Turin was 99 for stomach cancer and 93 for lung cancer. ${ }^{4}$

No association with duration of exposure was found for oral cancer. Risks for cancers of the larynx and pleura were highest in the categories with the longest duration of exposure (five observed $v 1 \cdot 1$ expected for larynx, two observed $v 0.2$ expected for pleura), although neither showed a statistically significant trend with increasing duration. The SMR for total cancer mortality was 108 (95\% confidence interval $(\mathrm{CI})=86-135)$.

Table 2 shows results for selected non-neoplastic causes of death and mortality from all causes. An excess in total mortality existed, with 427 observed $v$ 286.3 expected deaths $(S M R=149)$, together with substantial excesses in mortality from asbestosis (16 observed deaths), hepatic cirrhosis, and other causes such as accidents (47 observed $v 24.3$ expected deaths), and unspecified cardiovascular diseases (100 observed $v 61.4$ expected deaths). None of these causes, however, showed a duration risk relation and the SMRs for cirrhosis and accidents were highest for the workers with the shortest duration of employment.

Table 3 gives mortality from cancers of the larynx, lung, pleura, from all cancers, and from all causes in separate categories of age at first exposure, time since first and last exposure, and cumulative dust exposure. For laryngeal cancer, the risk was apparently greater for workers exposed at a younger age, and within shorter periods since first or last exposure. It should be noted, however, that these three time factors are closely interrelated, and it is difficult, on the basis of only eight deaths, to distinguish which, if any, is the main component. There was a trend towards greater risk with increasing cumulative dust exposure that approached significance ( $p=0.05$, one sided).

On the basis of 22 observed deaths, no consistent

Table 1 Mortality experience from selected cancer sites in a cohort of chrysotile asbestos miners in Balangero, northern Italy. Expected numbers are based on national death rates in each five year calendar period and age group. Deaths and man-years beyond age 80 are excluded

\begin{tabular}{|c|c|c|c|c|c|c|c|c|c|c|c|c|}
\hline \multirow[b]{3}{*}{ Cause of death } & \multicolumn{12}{|c|}{ No of observed and expected deaths by duration of exposure (y) } \\
\hline & \multicolumn{3}{|c|}{$<10$} & \multicolumn{3}{|c|}{$10-20$} & \multicolumn{3}{|c|}{$>20$} & \multicolumn{3}{|c|}{ Total } \\
\hline & $O$ & $E$ & $O / E$ & $O$ & $E$ & $O / E$ & $O$ & $E$ & $O / E$ & $O$ & $E$ & $O / E$ \\
\hline $\begin{array}{l}\text { Oro-pharyngeal cancer } \\
\text { Gastric cancer } \\
\text { Intestinal cancer } \\
\text { Liver cancer } \\
\text { Laryngeal cancer } \\
\text { Lung cancer } \\
\text { Pleural cancer }\end{array}$ & $\begin{array}{r}5 \\
4 \\
3 \\
0 \\
3 \\
10 \\
0\end{array}$ & $\begin{array}{l}1 \cdot 1 \\
5 \cdot 8 \\
2 \cdot 9 \\
0 \cdot 7 \\
1 \cdot 3 \\
8 \cdot 5 \\
0 \cdot 1\end{array}$ & $\begin{array}{l}4.5 \\
0.7 \\
1.0 \\
2 \cdot 3 \\
1.2 \\
-\end{array}$ & $\begin{array}{l}1 \\
5 \\
0 \\
0 \\
0 \\
4 \\
0\end{array}$ & $\begin{array}{l}0 \cdot 5 \\
2 \cdot 8 \\
1 \cdot 3 \\
0 \cdot 3 \\
0 \cdot 6 \\
3 \cdot 8 \\
0 \cdot 0\end{array}$ & $\begin{array}{l}2.0 \\
1.8 \\
= \\
= \\
1 \cdot 1\end{array}$ & $\begin{array}{l}0 \\
3 \\
3 \\
3 \\
5 \\
8 \\
2\end{array}$ & $\begin{array}{l}0.9 \\
4 \cdot 0 \\
2 \cdot 3 \\
0 \cdot 7 \\
1 \cdot 1 \\
7 \cdot 6 \\
0 \cdot 2\end{array}$ & $\begin{array}{r}\overline{-} \\
0 \cdot 8 \\
1 \cdot 3 \\
4 \cdot 3 \\
4 \cdot 6 \\
1 \cdot 1 \\
10 \cdot 0\end{array}$ & $\begin{array}{r}6 \\
12 \\
6 \\
3 \\
8 \\
22 \\
2\end{array}$ & $\begin{array}{r}2 \cdot 6 \\
12 \cdot 7 \\
6 \cdot 6 \\
1 \cdot 7 \\
3 \cdot 0 \\
19 \cdot 9 \\
0 \cdot 3\end{array}$ & $\begin{array}{l}2.3 \\
0.9 \\
0.9 \\
1.8 \\
2.7 \\
1.1 \\
6.7\end{array}$ \\
\hline All cancers & 36 & $34 \cdot 0$ & $1 \cdot 1$ & 14 & $15 \cdot 7$ & 0.9 & 32 & $26 \cdot 5$ & $1 \cdot 2$ & 82 & $76 \cdot 2$ & $1 \cdot 1$ \\
\hline
\end{tabular}

$\mathrm{O}=$ Observed deaths; $\mathrm{E}=$ expected deaths. 
Table 2 Mortality experience from selected non-neoplastic diseases and all causes of death in a cohort of chrysotile asbestos miners in Balangero, northern Italy. Expected numbers are based on national death rates in each five year calendar period and age group. Deaths and man-years beyond age 80 are excluded

\begin{tabular}{|c|c|c|c|c|c|c|c|c|c|c|c|c|}
\hline \multirow[b]{3}{*}{ Cause of death } & \multicolumn{12}{|c|}{ No of observed and expected deaths by duration of exposure (y) } \\
\hline & \multicolumn{3}{|c|}{$<10$} & \multicolumn{3}{|c|}{$10-20$} & \multicolumn{3}{|c|}{$>20$} & \multicolumn{3}{|c|}{ Total } \\
\hline & $O$ & $E$ & $O / E$ & $O$ & $E$ & $O / E$ & $O$ & $E$ & $O / E$ & $O$ & $E$ & $O / E$ \\
\hline $\begin{array}{l}\text { Ischaemic heart disease } \\
\text { Stroke } \\
\text { Asbestosis } \\
\text { Chronic respiratory disease } \\
\text { Hepatic cirrhosis } \\
\text { Accidents and violence }\end{array}$ & $\begin{array}{r}16 \\
20 \\
3 \\
8 \\
23 \\
34\end{array}$ & $\begin{array}{c}20 \cdot 6 \\
13 \cdot 9 \\
0 \\
5 \cdot 6 \\
6 \cdot 7 \\
12 \cdot 8\end{array}$ & $\begin{array}{l}0.8 \\
1 \cdot 4 \\
1 \cdot 4 \\
3 \cdot 4 \\
2 \cdot 7\end{array}$ & $\begin{array}{r}11 \\
2 \\
5 \\
3 \\
11 \\
8\end{array}$ & $\begin{array}{l}9 \cdot 8 \\
6 \cdot 6 \\
0 \\
2 \cdot 6 \\
3 \cdot 2 \\
5 \cdot 7\end{array}$ & $\begin{array}{l}1 \cdot 1 \\
0 \cdot 3 \\
1 \cdot 2 \\
3 \cdot 4 \\
1 \cdot 4\end{array}$ & $\begin{array}{r}10 \\
9 \\
8 \\
5 \\
11 \\
5\end{array}$ & $\begin{array}{c}15 \cdot 6 \\
9 \cdot 8 \\
0 \\
4 \cdot 4 \\
5 \cdot 4 \\
5 \cdot 7\end{array}$ & $\begin{array}{l}0.6 \\
0.9 \\
\overline{1.1} \\
2 \cdot 0 \\
0.9\end{array}$ & $\begin{array}{l}37 \\
31 \\
16 \\
16 \\
45 \\
47\end{array}$ & $\begin{array}{c}45 \cdot 9 \\
30 \cdot 3 \\
0 \\
12 \cdot 6 \\
15 \cdot 3 \\
24 \cdot 2\end{array}$ & $\begin{array}{l}0.8 \\
1.0 \\
1.3 \\
2.9 \\
1.9\end{array}$ \\
\hline All causes & 225 & $132 \cdot 6$ & 1.7 & 85 & $62 \cdot 1$ & 1.4 & 117 & 91.6 & $1 \cdot 3$ & 427 & $286 \cdot 3$ & 1.5 \\
\hline Man-years (No of subjects) & \multicolumn{3}{|c|}{$15025(459)$} & \multicolumn{3}{|c|}{$6641(293)$} & \multicolumn{3}{|c|}{$5344(306)$} & \multicolumn{3}{|c|}{$27010(1058)$} \\
\hline
\end{tabular}

$\mathrm{O}=$ Observed deaths; $\mathrm{E}=$ expected deaths.

pattern of risk for lung cancer was evident for any of the time factors considered, nor for cumulative exposure to fibres. The two deaths from pleural cancer were in the highest categories of cumulative dust exposure.

None of the temporal factors considered or the measure of cumulative exposure to dust showed a clear pattern of risk with total mortality from cancer or all causes of death.

\section{Discussion}

The update on data for this cohort of chrysotile miners confirmed a substantial excess in total mortality, and the absence of important associations with mortality from cancer. The SMR for total mortality from cancer was only just above unity, and no significant excess was found in mortality from lung cancer.
This varies from the pattern commonly found in cohorts of workers, as total mortality, and particularly mortality from cardiovascular disease, tend to be lower than expected (the healthy worker effect), whereas mortality from cancer is usually less affected by this selection mechanism. ${ }^{7}$ A possible explanation for this peculiarity in the current study may relate to the drinking habits of the miners. ${ }^{1}$

For the two deaths reported as due to pleural mesothelioma, the diagnosis was based on clinical and radiological findings and examination of pleural fluid in one case and on histological examinations of specimens from thoracotomy in the other. The expected value for mesothelioma was 0.3 . The SMR is of borderline statistical significance, and this, together with the observation that both deaths were found among the group of workers exposed for more than 20 years, suggests that exposure to this

Table 3 Mortality experience from selected cancer sites and total mortality in a cohort of chrysotile asbestos miners in Balangero, northern Italy according to various exposure measures. Expected numbers are based on national death rates in each five year calendar period and age $\overline{0}$ group. Deaths and man-years beyond age 80 are excluded

\begin{tabular}{|c|c|c|c|c|c|c|c|c|c|c|c|c|c|c|c|c|}
\hline \multirow[b]{2}{*}{ Variables } & \multicolumn{3}{|c|}{ Larynx } & \multicolumn{3}{|c|}{ Lung } & \multicolumn{3}{|c|}{ Pleura } & \multicolumn{3}{|c|}{ All cancer } & \multicolumn{3}{|c|}{ All causes } & \multirow{2}{*}{$\begin{array}{l}\text { Man-years } \\
\text { (No of } \\
\text { subjects) }\end{array}$} \\
\hline & $O$ & $E$ & $O / E$ & $O$ & $E$ & $O / E$ & $O$ & $E$ & $O / E$ & $O$ & $E$ & $O / E$ & $O$ & $E$ & $O / E$ & \\
\hline \multicolumn{17}{|c|}{ Age at first exposure $(y)$ : } \\
\hline $\begin{array}{l}<30 \\
\geqslant 30\end{array}$ & $\begin{array}{l}5 \\
3\end{array}$ & $\begin{array}{l}1.4 \\
1.6\end{array}$ & $\begin{array}{l}3.6 \\
1.9\end{array}$ & $\begin{array}{r}8 \\
14\end{array}$ & $\begin{array}{r}10 \cdot 1 \\
9 \cdot 9\end{array}$ & $\begin{array}{l}0 \cdot 8 \\
1 \cdot 4\end{array}$ & $\begin{array}{l}1 \\
1\end{array}$ & $\begin{array}{l}0 \cdot 1 \\
0 \cdot 1\end{array}$ & $\begin{array}{l}10 \cdot 0 \\
10 \cdot 0\end{array}$ & $\begin{array}{l}34 \\
48\end{array}$ & $\begin{array}{l}34 \cdot 3 \\
41 \cdot 9\end{array}$ & $\begin{array}{l}1 \cdot 0 \\
1 \cdot 1\end{array}$ & $\begin{array}{l}183 \\
244\end{array}$ & $\begin{array}{l}119 \cdot 1 \\
167 \cdot 3\end{array}$ & $\begin{array}{l}1 \cdot 5 \\
1 \cdot 5\end{array}$ & $\begin{array}{r}17478(629) \\
9532(429)\end{array}$ \\
\hline \multicolumn{17}{|c|}{ Time since first exposure $(y)$ : } \\
\hline $\begin{array}{l}<20 \\
20-30 \\
>30\end{array}$ & $\begin{array}{l}2 \\
2 \\
4\end{array}$ & $\begin{array}{l}0 \cdot 5 \\
0 \cdot 8 \\
1 \cdot 7\end{array}$ & $\begin{array}{l}4 \cdot 0 \\
2 \cdot 5 \\
2 \cdot 4\end{array}$ & $\begin{array}{r}3 \\
7 \\
12\end{array}$ & $\begin{array}{r}2 \cdot 6 \\
4 \cdot 7 \\
12 \cdot 6\end{array}$ & $\begin{array}{l}1 \cdot 2 \\
1 \cdot 5 \\
1 \cdot 0\end{array}$ & $\begin{array}{l}0 \\
1 \\
1\end{array}$ & $\begin{array}{l}0 \cdot 0 \\
0 \cdot 1 \\
0 \cdot 2\end{array}$ & $\begin{array}{r}-10 \cdot 0 \\
5 \cdot 0\end{array}$ & $\begin{array}{l}14 \\
22 \\
46\end{array}$ & $\begin{array}{l}13 \cdot 2 \\
19 \cdot 6 \\
43 \cdot 4\end{array}$ & $\begin{array}{l}1 \cdot 1 \\
1 \cdot 1 \\
1 \cdot 1\end{array}$ & $\begin{array}{l}110 \\
119 \\
198\end{array}$ & $\begin{array}{r}61 \cdot 0 \\
75 \cdot 5 \\
149 \cdot 9\end{array}$ & $\begin{array}{l}1 \cdot 8 \\
1 \cdot 6 \\
1 \cdot 3\end{array}$ & $\begin{array}{r}14983(327) \\
6325(219) \\
5702(512)\end{array}$ \\
\hline \multicolumn{17}{|c|}{ Time since last exposure $(y)$ : } \\
\hline $\begin{array}{l}\text { exposure } \\
\leqslant 10 \\
>10\end{array}$ & $\begin{array}{l}2 \\
3 \\
3\end{array}$ & $\begin{array}{l}0 \cdot 5 \\
0 \cdot 7 \\
1 \cdot 8\end{array}$ & $\begin{array}{l}4 \cdot 0 \\
4 \cdot 3 \\
1 \cdot 7\end{array}$ & $\begin{array}{r}2 \\
6 \\
14\end{array}$ & $\begin{array}{r}2 \cdot 7 \\
4 \cdot 5 \\
12 \cdot 7\end{array}$ & $\begin{array}{l}0 \cdot 7 \\
1 \cdot 3 \\
1 \cdot 1\end{array}$ & $\begin{array}{l}1 \\
1 \\
0\end{array}$ & $\begin{array}{l}0 \cdot 0 \\
0 \cdot 1 \\
0 \cdot 2\end{array}$ & $\overline{10} \cdot 0$ & $\begin{array}{l}11 \\
25 \\
46\end{array}$ & $\begin{array}{l}11 \cdot 5 \\
16 \cdot 9 \\
47 \cdot 9\end{array}$ & $\begin{array}{l}1.0 \\
1.5 \\
1.0\end{array}$ & $\begin{array}{r}69 \\
109 \\
249\end{array}$ & $\begin{array}{r}47 \cdot 2 \\
61 \cdot 6 \\
177 \cdot 6\end{array}$ & $\begin{array}{l}1.5 \\
1.8 \\
1.4\end{array}$ & $\begin{array}{r}11651(270) \\
5963(204) \\
9396(584)\end{array}$ \\
\hline \multicolumn{17}{|c|}{ Cumulative dust exposure (fibre-years): } \\
\hline $\begin{array}{l}<100 \\
100-400 \\
>400\end{array}$ & $\begin{array}{l}1 \\
2 \\
5\end{array}$ & $\begin{array}{l}0.7 \\
0.9 \\
1.3\end{array}$ & $\begin{array}{l}1 \cdot 4 \\
2 \cdot 2 \\
3 \cdot 8\end{array}$ & $\begin{array}{r}4 \\
8 \\
10\end{array}$ & $\begin{array}{l}5 \cdot 1 \\
6 \cdot 1 \\
8 \cdot 7\end{array}$ & $\begin{array}{l}0 \cdot 8 \\
1 \cdot 3 \\
1 \cdot 1\end{array}$ & $\begin{array}{l}0 \\
1 \\
1\end{array}$ & $\begin{array}{l}0 \cdot 1 \\
0 \cdot 1 \\
0 \cdot 1\end{array}$ & $\begin{array}{l}-10 \cdot 0 \\
10 \cdot 0\end{array}$ & $\begin{array}{l}14 \\
27 \\
41\end{array}$ & $\begin{array}{l}19 \cdot 1 \\
23 \cdot 8 \\
33 \cdot 3\end{array}$ & $\begin{array}{l}0 \cdot 7 \\
1 \cdot 1 \\
1 \cdot 2\end{array}$ & $\begin{array}{r}93 \\
162 \\
172\end{array}$ & $\begin{array}{r}70 \cdot 9 \\
91 \cdot 2 \\
124 \cdot 2\end{array}$ & $\begin{array}{l}1 \cdot 3 \\
1 \cdot 8 \\
1 \cdot 4\end{array}$ & $\begin{array}{l}9036(410) \\
8195(327) \\
9779(321)\end{array}$ \\
\hline
\end{tabular}


chrysotile asbestos, or to other fibres contaminating chrysotile, or both, is associated with moderate, excess risk of mesothelioma. Similarly, it was suggested that the excess risk of mesothelioma found among Quebec chrysotile workers may have been due to contamination with tremolite. ${ }^{89}$ This suggestion was also made for mesothelioma cases found in Cyprus. ${ }^{10}$

In our study, examination of several samples of chrysotile from the mine ruled out the presence of contamination with fibrous amphiboles at detectable concentrations. A fibrous silicate (balangeroite) was characterised, however, consisting of brown, rigid, and brittle xyloid fibres with a complex structure similar to gageite, usually intergrown with chrysotile. ${ }^{11}$

Compagnoni et al ${ }^{11}$ reported the empirical formula for the unit cell of balangeroite to be:

$\left(\mathrm{Mg}_{25.70} \mathrm{Fe}_{7.69}^{2+} \mathrm{Fe}_{3.63}^{3+} \mathrm{Mn}_{1.65}^{2+}\right.$

$\left.\mathrm{Al}_{0.17} \mathrm{Ca}_{0.07} \mathrm{Cr}_{0.01} \mathrm{Ti}_{0.01}\right)_{233.93} \mathrm{Si}_{15: 38} \mathrm{O}_{53,66}(\mathrm{OH})_{35.92}$

Figure 1 shows the morphological aspects of these fibres from scanning electron microscope studies. The smallest diameters for elemental balangeroite fibres are of the same order as those of amphibole asbestos-namely, $0 \cdot 1-2 \cdot 0 \mu$, by contrast with chrysotile, the fibrils of which have diameters as low as $0.02 \mu$.

Figure 2 shows the spectrum resulting from energy dispersive $x$ ray analysis of balangeroite, with peaks of $\mathrm{Fe}$ and $\mathrm{Mn}$, two cations prominent in its chemical composition.

Balangeroite accounts for $0.2-0.5 \%$ of the total mass of samples of chrysotile as commercialised from the Balangero mine. Nothing is at present known about its adverse effects, although they can be suspected on the basis of its fibre dimensions being similar to those of amphiboles. A contribution from these fibres in inducing the two cases of mesothelioma cannot, therefore, be ruled out.

The absence of excess mortality from lung cancer is more difficult to interpret, as there is no clear evidence that chrysotile causes a smaller risk than amphibole asbestos, ${ }^{12}{ }^{13}$ although excess of lung cancer was low or absent in workers using only chrysotile, for example, those employed in production of friction material. ${ }^{14-17}$ In other groups of chrysotile miners, such as the large Quebec cohort, ${ }^{18}$ the SMR for respiratory cancers was in agreement with the results of our study only in the overall data $(\mathrm{SMR}=125$, based on 230 observed $v 184$ expected deaths); the estimated excess risk for Quebec miners was 2.6 in the subgroup with the highest exposure and duration of employment, by contrast with our study where there was little increased risk even in the most heavily exposed workers.

Substantial excesses for lung cancer, on the other hand, were seen in textile plants using chrysotile, ${ }^{19-22}$ although it is still doubtful whether or not concomitant exposure to amphiboles occurred in some of

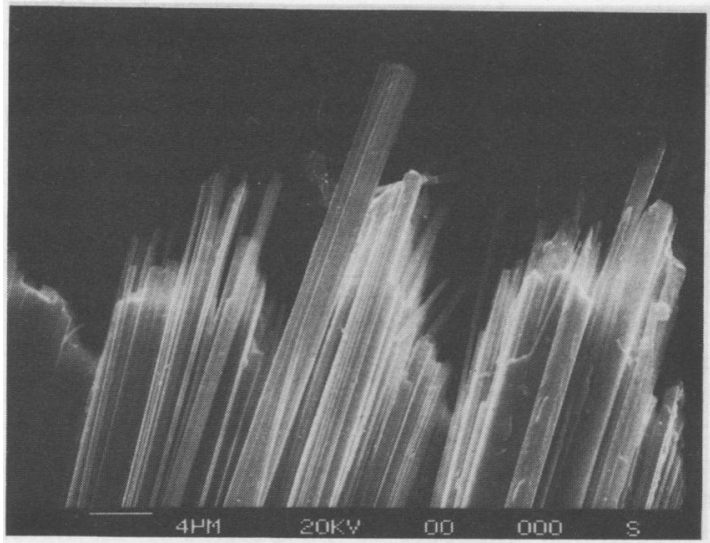

Figure 1 A scanning electron microscope view of a typical balangeroite fibre consisting of elemental units with various diameters ranging from 0.2 to $1.5 \mu$.

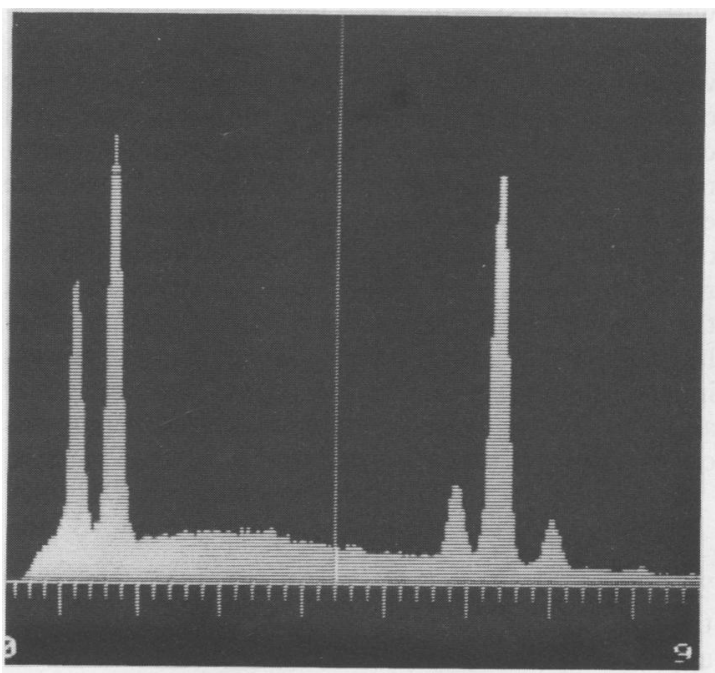

Figure 2 Element peaks identified by energy dispersive $x$ ray analysis. The peaks, ranging from $0-9$ are: $1 \cdot 2 \mathrm{Mg}$, 1.8 Si, 4.6 Ca, 5.8 Mn (primary peak), 6.4 Mn (secondary peak) and $\mathrm{Fe}$ (primary peak), $7 \mathrm{Fe}$ (secondary peak).

these factories. ${ }^{2122}$ The results of the present study, none the less, are compatible with a risk of lung cancer some $60 \%$ greater than normal (upper $95 \%$ CI of the SMR = 167), and probably even with a somewhat higher risk, as rates in the late 1940 s were lower than those of the mid-1950s utilised for the computation of expected values in our analyses. The low incidence of lung cancer found in our cohort, particularly in men whose cumulative exposure exceeded 400 fibres per ml-year, is inconsistent with the dose specific risk estimate proposed by Doll and Peto (a $1 \%$ increase in relative risk per fibre ml-year ${ }^{23}$ ). This would predict over 35 cases at this degree of exposure, whereas only 10 were found. A 
further unusual aspect of these data is the ratio of asbestosis to lung cancer, although this can be partly explained in terms of overdiagnosis of asbestosis.

Exposure to asbestos has been linked to increased risk of laryngeal cancer (although conclusions were not definite $)^{23-25}$ but there was no clear evidence for increased risk of cancer of digestive sites. ${ }^{23}$ As mortality was increased for alcohol related disease, including cancer of the oral cavity, pharynx, liver, hepatic cirrhosis, and accidents in this cohort, it is conceivable that at least part of the excess risk for laryngeal cancer can be attributed to high alcohol consumption. Comparison of the duration risk relation for hepatic cirrhosis and laryngeal cancer, however, suggests that some direct relation with occupational exposure is possible. For laryngeal cancer the SMR was 158 for less than 20 years of exposure and $\mathbf{4 5 6}$ for longer duration, whereas for hepatic cirrhosis the SMR was greater for workers with short (343) rather than long (204) exposure.

Thus although the number of deaths from cancer were still too limited to allow us to draw definite conclusions, updated analysis of the mortality of this cohort of chrysotile miners and inspection of duration and amount of exposure indicates that some excess of laryngeal and pleural cancer (but not of other causes of death except asbestosis) may be related to occupational exposure. On the other hand, there was little evidence of excess mortality from lung cancer. This finding, and the substantial excess in non-neoplastic mortality, possibly explained by alcohol related deaths, represent peculiarities for this cohort of chrysotile miners.

This work was conducted within the framework of the CNR (Italian National Research Council) applied projects "Oncology" (contract No 87.01544.44) and Risk Factors for Disease. The contributions of the Italian League Against Tumours and the Italian Association for Cancer Research, Milan, Italy are gratefully acknowledged. We thank Prof G F Rubino for providing the data, 'Ms J Baggott, Ms M P Bonifacino, and the G A Pfeiffer Memorial Library Staff for editorial assistance.

Requests for reprints to: Carlo La Vecchia, MD, Istituto di Ricerche Farmacologiche "Mario Negri". Via Eritrea, 62-20157 Milan, Italy.
1 Rubino GF, Piolatto G, Newhouse ML, Scansetti G, Aresini GA, Murray R. Mortality of chrysotile asbestos workers at the Balangero Mine, Northern Italy. Br J Ind Med 1979;36: 18794.

2 ISTAT (Istituto Centrale di Statistica). Annuario statistico Italiano. Roma: ISTAT, 1951-86 (various issues).

3 Decarli A, La Vecchia C. Cancer mortality in Italy, 1955-78. La mortalità per tumori in Italia, 1955-78. Tumori 1984; 70(suppl):579-742.

4 Cislaghi C, Decarli A, La Vecchia C, Laverda N, Mezzanotte G, Smans M. Dati, indicatori e mappe di mortalità tumorale. Data, statistics and maps on cancer mortality. Italia 1975/1977. Bologna: Pitagora Editrice, 1986.

5 La Vecchia C, Decarli A, Mezzanotte G, Cislaghi C. Mortality from alcohol related disease in Italy. $J$ Epidemiol Community Health 1986;40:257-61.

6 Terracini B, Anglesio E, Panero M, Vaneis P. Descriptive epidemiology of cancer of the larynx in the province of Torino, Italy. Tumori 1978;64:445-56.

7 Breslow NE, Day NE. Statistical methods in cancer research. Vol II. The design and analysis of cohort studies. Lyon: International Agency for Research on Cancer, 1980. (IARC sci publ No 82.)

8 Churg A, Wiggs B, Depaoli L, Kampe B, Stevens B. Lung asbestos content in chrysotile workers with mesothelioma. $\mathrm{Am}$ Rev Respir Dis 1984;130:1042-5.

9 McDonald JC, Armstrong B, Case B, et al. Mesothelioma and asbestos fiber type. Evidence from lung tissue analyses. Cancer 1989;63:1544-7.

10 McConnochie K, Simonato L, Mavrides P, Christofides P, Pooley FD, Wagner JC. Mesothelioma in Cyprus: The role of tremolite. Thorax 1987;42:342-7.

11 Compagnoni R, Ferraris G, Fiora L. Balangeroite, a new fibrous silicate related to gageite from Balangero, Italy. American Mineralogist 1983;68:214-9.

12 Doll R. Mineral fibres in the non-occupational environment: concluding remarks. Lyon: International Agency for Research on Cancer 1989:511-8. (IARC sci publ No 90.)

13 Peto J. Fibre carcinogenesis and environmental hazards. Lyon: International Agency for Research on Cancer 1989:457-70. (IARC sci publ No 90.)

14 Berry G, Newhouse ML. Mortality of workers manufacturing friction materials using asbestos. $\mathrm{Br} J$ Ind Med 1983;40:1-7.

15 Weiss W. Mortality of a cohort exposed to chrysotile asbestos. J Occup Med 1977;19:737-40.

16 McDonald AD, Fry JS, Woolley AJ, McDonald JC. Dust exposure and mortality in an American chrysotile asbestos friction products plant. Br J Ind Med 1984;41:151-7.

17 Mossman BT, Gee JBL. Asbestos-related diseases. $N$ Engl J Med 1989;320:1721-30.

18 McDonald JC, Liddell FDK, Gibbs GW, Eyssen GE, McDonald AD. Dust exposure and mortality in chrysotile mining, 1910-75. Br J Ind Med 1980;37:11-24.

19 Dement JM, Harris RL Jr, Symons MJ, Shy C. Estimates of dose-response for respiratory cancer among chrysotile asbestos textile workers. Ann Occup Hyg 1982;26:869-87.

20 McDonald AD, Fry JS, Woolley AJ, McDonald J. Dust exposure and mortality in an American chrysotile textile plant. Br J Ind Med 1983;40:361-7.

21 Peto J, Doll R, Howard SV, Kinlen LJ, Lewinsohn HC. A mortality study among workers in an English asbestos factory. Br J Ind Med 1977;34:169-73.

22 Newhouse ML, Berry G. Patterns of mortality in asbestos factory workers in London. Ann NY Acad Sci 1979;330: 53-60.

23 Doll R, Peto J. Asbestos: Effects on health of exposure to asbestos (Health and Safety Executive.) London: HMSO, 1985.

24 Chan CK, Gee JBL. Asbestos exposure and laryngeal cancer: An analysis of the epidemiologic evidence. J Occup Med 1988; 30:23-7.

25 Edelman D. Laryngeal cancer and occupational exposure to asbestos. Int Arch Occup Environ Health 1989;61:223-7.

Accepted 14 May 1990 